\title{
ANALYSIS OF CASH EXPENDITURE EFFECTIVENESS THROUGH THE ACCOUNTING INFORMATION SYSTEM OF PT. TELKOM INDONESIA REGIONAL DIVISION V
}

\author{
Mutiara Rachma Ardhiani ${ }^{1}$, Yuni Sukandani ${ }^{2}$, Siti Istikhoroh ${ }^{3}$, Yurida Sasmita ${ }^{4}$ \\ University of PGRI Adi Buana, Indonesia \\ Email: mutiara@ unipasby.ac.id
}

\begin{abstract}
:
This study aims to analyze the procedures and effectiveness of cash expenditure through the accounting information system of PT. Telkom Indonesia Regional Division (Divre) V. This type of research is descriptive qualitative with the Miles and Hubermen model as a method of analysis. The results showed that the company had implemented computerized financial management through SAP (System Application and Product) and cash expenditure using the imprest fund system. The use of accounting information systems and procedures aims to protect assets and support the effectiveness of cash expenditure.
\end{abstract}

Keywords: accounting information systems, effectiveness, cash expenditure.

\section{Background}

Business is one of the most complex activities and requires careful thinking and careful action in making decisions, especially in matters related to planning and evaluating the financial business development of a business or company (Afkar, 2017: 1). Financial measures can be generated easily if the company has an adequate information system so that at any time management can read, analyze, and then make decisions immediately (Mariana et al., 2017: 32).

The accounting information system plays an important role in the management of information regarding transactions related to the company's business activities (Krismiaji, 2015: 9). The accounting information system is used as a system that facilitates the management and protection of company finances (Mulyani et al., 2018: 22). So that the company's finances are always adequate in meeting the needs of the company, in addition to looking for sources of funds, the company must also regulate the use of the funds obtained. To be able to regulate the use of funds appropriately, companies need to control cash expenditure appropriately. This is done so that the company's expenditure budget is under the initial plan that has been determined (Lubis, 2017: 359).

Generally, the effectiveness of cash control is very much needed in carrying out business activities as well as for maintaining the viability (continuity) of the company. Cash is an asset that easily changes hands, therefore cash control must be done so that existing expenses can be controlled from the sources of income obtained (Afkar,178: 2017).

PT. Telkom Indonesia Regional Division (Divre) V was chosen as research object based on pre-research conducted by researchers indirectly and directly regarding the existing conditions and problems. The indirect pre-research was carried out by digging up information through online sources accessed from the company's official website. Data was obtained that PT. Telekomunikasi Indonesia is a state-owned company in the field of telecommunications and information media as well as edutainment of telecommunications infrastructure. PT. Telekomunikasi Indonesia has 7 Regional Telkom offices spread across Indonesia. One of them 
International Journal of Economics, Business and Accounting Research (IJEBAR)

Peer Reviewed - International Journal

Vol-4, Issue-3, 2020 (IJEBAR)

E-ISSN: 2614-1280 P-ISSN 2622-4771

https://jurnal.stie-aas.ac.id/index.php/IJEBAR

is in East Java, namely PT. Telkom Indonesia Divre V, which is the Telkom office in charge of business operations for the provinces of East Java, Bali, and Nusa Tenggara.

At the end of 2019, Telkom's financial performance increased in several posts. Profit for the year amounted to IDR 23,200 billion or increased 12.1\%, total assets of IDR 214,990 billion or increased $4.2 \%$, total liabilities of IDR 98,544 billion, or increased $10.9 \%$. The increase in total assets and liabilities was due to ongoing infrastructure development. But in the same year, total equity was recorded at IDR 116,446 billion or a decreased $0.7 \%$ from the previous year. Based on the data on the value of earnings, total assets and total liabilities have increased while total equity has decreased. It is strongly worthy to conduct further research on what kind of information system Telkom uses to manage its finances in a condition where debt and profits are increasing, even though its capital has decreased.

Meanwhile, based on direct pre-research, the researcher went to and observed the existing conditions and problems directly and obtained an overview of the cash expenditure activities handled by the Finance Service Division. In carrying out its duties, the Finance Service Division uses systemized accounting information to produce information about transactions as well as protection for cash expenditure. The accounting information system that has been used by Telkom, both in the head office and in the region, has used SAP (System Application and Product) which is supported by FINEST (Financial Enhanced Supporting Tools). However, in addition to the information from computerized accounting, the implementation of systemized accounting information still has weaknesses, such as errors in data entry or nominal numbers that affect journals for bookkeeping.

\section{Literature Review}

Effectiveness is the result of an administration that is funded following the results obtained from the initial plan for the objectives of an institution. The measure of the effectiveness of cash expenditures is an aspect of controlling cash expenditures in a business organization. Internal protection of the cash out process will prevent errors or fraud so that cash expenditures can be said to be effective (Zamzani et al., 2018: 111). Accounting information for cash expenditures will be better if it has adequate and systemized control procedures. Manual and computerized control systems will give different results, but they have the same goal, it is for the accuracy of the information produced so that decision-makers can trust in making the right decisions (Krismiaji, 2015: 357).

Cash expenditure is a transaction management activity related to cash out. Cash expenditures are related to the company's main activities related to four transaction activities, such as purchasing goods, recording debt, receiving goods, and paying off debts (Krismiaji, 2015: 343). The petty cash fund system is divided into two, they are the imprest fund system and the fluctuating fund system (Ismail, 2015: 139). The imprest fund system is a petty cash fund system that is formed and will be filled in according to the initial balance of petty cash at the initial fund formation. Journals are made only at the time of formation, while during expenditure, all transactions are not journalized but only the proof is archived. Meanwhile, the fluctuating fund system is a petty cash fund system whose balance is always changing or fluctuating from the initial balance of formation. This is because journaling is not only done at the time of the formation of the initial balance but also when the cash expenditure transaction occurs.

The accounting information system is a transaction data management system to process output in the form of useful information in business processes including planning, operation, and controlling (Krismiaji, 2015: 4). Accounting information systems can be implemented without computer aids (manual), but also with computer aids or the latest information technology, or through a combination of both (Krismiaji, 2015: 5).

The effectiveness of internal control of cash expenditures occurs through well-executed company financial systems and procedures (Suryadi \& Yulyana, 2016). The implementation of 
International Journal of Economics, Business and Accounting Research (IJEBAR)

Peer Reviewed - International Journal

Vol-4, Issue-3, 2020 (IJEBAR)

E-ISSN: 2614-1280 P-ISSN 2622-4771

https://jurnal.stie-aas.ac.id/index.php/IJEBAR

cash expenditure procedures is not optimal due to the application of an accounting information system that does not support the existing expenditure transaction management process (Hartati, Irwadi \& Damayanti, 2017).

The cash expenditure procedure will be effective through the maximum implementation of the cash expenditure control aspects contained in the procedure. Applying the elements of internal control for cash expenditures correctly will affect the effectiveness of cash expenditures. The suitability of the elements and objectives in a company's internal control system procedures with the direct practice of controlling cash expenditures is an indicator that cash expenditures are effective (Lisma \& Oktariansyah, 2018).

\section{Method}

This research is a qualitative based on the view of postpositivism as a constructive interpretive model, by looking at the social activity as a complex, balanced, and meaningful, through interactions between the objects studied (Sugiyono, 2017: 25). Qualitative research is carried out with natural objects, namely real objects, originally without engineering, even the presence of researchers will not have an effect on the object under study. Meanwhile, the supporting tools or facilities are the person (the researcher).

Sources of research data are primary and secondary data sources, with documentation, observation, and interviews as data collection techniques. Then the research results obtained are tested for validity through triangulation. Followed by the analysis of the model of Miles and Huberman. From the results of this analysis, conclusions will be drawn and given input for the company and further researchers.

\section{Results}

The results of research on the effectiveness of cash expenditures through the accounting information system at PT. Telkom Indonesia Divre V shows that cash expenditures have been implemented effectively and efficiently. This is evidenced by the implementation of a computerized accounting information system using SAP and FINEST as supporting applications that help smooth cash expenditure procedures with the existing imprest fund method such as journal making and transaction documents related to filling, use, and accountability of imprest funds.

The use of SAP applications and FINEST help control existing cash expenses with the appropriate division of job descriptions and position. Only officers in the relevant field can access that field, as well as check and reconciliation holders can only be accessed by Cash \& Bank Officers on SAP and FINEST. The posting process, recording transactions, archiving transaction documents, and verifying transaction data can only be accessed by the Verification Officer at SAP and FINEST.

There are restrictions and authorizations in signing cash expenditures automatically in SAP and FINEST, so when the funds filled in the application do not match the limits of funds that should be filled, the system cannot continue to the next data access until the data filled in is under inputting systemized fund limitation data. This also included in filling imprest funds. Every existing transaction must be accompanied by valid and complete documents and proof of transactions. Both electronic transaction data entered in the system and non-electronic transaction data in the form of a print out documents. If they are not complete and correct the Finance Manager cannot approve of them. For each month reconciliation is carried out, financial reporting to the head office via online posting and audit via the SAP system or auditors coming directly to the office.

Provision of advances and replenishment of imprest funds using reimbursement systems and virtual accounts. Journaling and posting are done online every day, precisely when there is a transaction or according to the bill. In this case, the Verification Officer will cross-check the evidence of the existing transaction as a requirement for disbursement of funds for each user, if 
International Journal of Economics, Business and Accounting Research (IJEBAR)

Peer Reviewed - International Journal

Vol-4, Issue-3, 2020 (IJEBAR)

E-ISSN: 2614-1280 P-ISSN 2622-4771

https://jurnal.stie-aas.ac.id/index.php/IJEBAR

it is not complete or not correct, the Verification Officer will return it to the user for correction so that it can be approved by the Finance Manager.

Filing cash receipts that are included by each user or third party client is equipped with a transaction proof number if it is complete and correct. The Verification Officer will check the checklist column and stamp it in full when it has been paid. These results are consistent with results of previous studies conducted by Lisma \& Oktariansyah (2018), that the internal control of cash expenditure includes the separation of duties, proof of cash that came with a proof number of transactions, the company stamped paid each of the transactions on the evidence of cash expenditures, so transactions already paid cannot be paid back when there is information that it has been paid.

The implementation of cash expenditures controls has been supported by the internal controls of the Sarbanes Oaxley Act (SOA) and Information Technology General Control (ITGC) on the rules related to the procedures for application control. These results are in line with the results of previous studies by Hartati et. al (2017) that the implementation and procedures for implementing cash expenditures are declared effective if they have been implemented according to the existing procedures in the company's internal cash expenditures control system.

\section{Conclusion}

1. PT. Telkom Indonesia Divre V has managed and computerized its finances systematically using information technology such as SAP (System Application and Product) as the main financial system and supported by the FINEST application (Financial Echanced Supporting Tools).

2. The Finance department handles cash expenditures for Regional V (East Java, Bali, and Nusa Tenggara). The cash expenditures system applied is the imprest fund system.

3. The company's cash expenditures have been effective. This can be seen based on the use of an accounting information system with SAP and FINEST, which is very supportive of existing cash expenditure procedures. So the use of cash expenditure transactions by procedures that apply to cash expenditure limits and authorization of existing transactions are controlled simultaneously in the SAP system.

\section{Implications}

The implication of the results of the discussion of this research data is useful as additional material, especially regarding the application of information generated from systemized accounting, so that company considerations can be used in determining and implementing future cash expenditure controls. Besides, the results of the discussion of this research data are useful for companies in assessing and evaluating the current accounting information system to improve future cash expenditure procedures to make them even better.

PT. Telekomunikasi Indonesia is expected to be able to develop better SAP and FINEST in the future so that they are not only able to detect errors (fraud) but also automatically create corrective journals, so for the branch office of PT. Telekomunikasi Indonesia Regional Divisions I to VII spread across Indonesia can post more quickly for financial reporting. To improve competence, company growth, maintain competitive advantage, and effectiveness of cash expenditures, PT. Telekomunikasi Indonesia is also expected to be able to update the accounting information system every year that can be applied to all branch offices of PT. Telekomunikasi Indonesia Regional Division I to VII.

\section{Research Limitation}

The focus of this research is the analysis of the effectiveness of extracting information about the cash expenditure through the accounting information system of PT. Telkom Indonesia Regional Division $\mathrm{V}$ and documentation as facts on the required data. The research carried out only used 
International Journal of Economics, Business and Accounting Research (IJEBAR)

Peer Reviewed - International Journal

Vol-4, Issue-3, 2020 (IJEBAR)

E-ISSN: 2614-1280 P-ISSN 2622-4771

https://jurnal.stie-aas.ac.id/index.php/IJEBAR

three research objects i.e cash expenditures, cash expenditure control, and accounting information systems. For further research, it is recommended to add new research objects that are more complex and followed by the addition of research subjects from several other fields in related companies.

\section{References}

Afkar, T. (2017). Penganggaran Bisnis. Surabaya: Unipa Pres.

Hartati, S., Irwadi, M., \& Damayanti, I. (2017). Penerapan Sistem Informasi Akuntansi Pengeluaran Kas pada PT Citra Bumi Sumatera Palembang. VI(I), 14-21.

Ismail. (2015). Akuntansi Bank: Teori dan Aplikasi dalam Rupiah. Jakarta: Prenada Media.

Krismiaji. (2015). Sistem Informasi Akuntansi. Yogyakarta: UPP SKIM YKPN.

Lisma, M., \& Oktariansyah. (2018). Analisis Prosedur Pengeluaran Kas pada PT Jasa Raharja (Persero) Cabang Sumatera Selatan. Jurnal Media Akuntansi, 1, 40-49.

Lubis, A. I. (2017). Akuntansi Keprilakuan. Jakarta: Salemba Empat.

Mariana, A., Syaban, S. I., Ma'ruf, W., \& Suarni., A. (2017). Sistem Informasi Akuntansi. Surabaya: UM Surabaya Publishing.

Mulyani, S., Suzan, L., Sagara, dkk. (2018). Sistem Informasi Akuntansi. Bandung: Unpad Pres.

Sugiyono. (2017). Metode Penelitian Bisnis (Pendekatan Kuantitatif, Kualitataif, Kombinasi, dan R\&D). Bandung: Alfabeta.

Suryadi, D., \& Yulyana, Y. (2016). Evaluasi Sistem Pengendalian Internal terhadap Efektivitas Pengeluaran Kas pada AJB Bumiputera 1912 Kantor Cabang Cimahi. Jurnal Akuntansi, $10(2), 1-74$.

Zamzani, F., Mukhlis, \& Pramesti, A. E. (2018). Audit Keuangan Sektor Publik untuk Keungan Pemerintah Daerah. Yogyakarta: UGM Press. 